\title{
EGBERTO PEREIRA
}

Análise Estratigráfica do Paleozóico Médio da Sub-Bacia do Alto Garças no Sudoeste de Goiás. Bacia do Paraná. Brasil.

Orientador: Maria Antonieta da C.Rodrigues

Resumo:

A análise estratigráfica do Paleozóico médio da sub-bacia do Alto Garças foi realizada a partir do estudo dos sedimentos associados à formações Vila Maria Furnas e Ponta Grossa registrados em uma ampla faixa de exposição no sudoeste de Goiás, e pela interpretação dos dados dos poços AGse-1-MT, SAse-1-GO e TLst-1-MT da Petrobrás. Foi possível, a partir dessa análise, redefinir as relações estratigráficas entre as unidades litoestratigráficas envolvidas e estabelecer um arcabouço de seqüências 
deposicionais para esse intervalo de tempo. No contexto da análise estratigráfica realizou-se um estudo faciológico de detalhe visando definir os sistemas deposicionais presentes na evolução sedimentar da sub-bacia. 